\title{
THE SISYPHUS EFFECT
}

\author{
SANDOR G. VARI \\ International Research and Innovation in Medicine Program, \\ Cedars - Sinai Medical Center, Los Angeles, CA 90048-5502, USA; \\ e-mail: Sandor.Vari@cshs.org
}

$\mathrm{S}$ cientific work for researchers, women and men equally, is an endless challenge. Determining new markers for early diagnosis of diseases, investigating the maintenance of cell and tissue homeostasis, studying metabolic regulation and dysregulation as well as intra-organ and interorgan crosstalk can be tiresome work and can sometimes seem like the punishment Zeus gave to Sisyphus. Sisyphus, the Greek mythological figure, was condemned to roll a boulder up a mountain but near the top of the mountain the boulder roll down; for eternity Sisyphus was forced to repeat this task over and over. Although scientific research can sometimes seem like this, the cleverness of scientists helps to overcome the "Sisyphus Effect". "I leave Sisyphus at the foot of the mountain. One always finds one's burden again. But Sisyphus teaches the higher fidelity that negates the gods and raises rocks" [1]. Sisyphus is a symbol of self-overcoming. Sisyphus was also infamous for his deception though, which had led Zeus to punish him to roll the boulder up a hill that rolled down repeatedly, and Sisyphus had to keep trying again and again for eternity [2].

While the vast majority of scientists are honest and work hard to achieve their research goals, some scientists are egotistical and may resort to trickery and doing things unethically. In Science the role of Sisyphus is played by the community of researchers, and to ensure that the boulder does not roll down the hill again. We researchers have to share our research results as well as repeat the published methods and research protocols again and again and these tasks can seem like "Sisyphean" work. Furthermore, in Science, the research community also plays the role of Zeus and will punish dishonesty so therefore we researchers must roll a boulder up a hill again and again and after we have proved that the published scientific work is sound, the "boulder" and the scientist will stay on top of the hill.

In the Association for Regional Cooperation in the Fields of Health, Science and Technology (RECOOP HST Association) scientists equally share the burden of Zeus and Sisyphus independently of the status of their $\mathrm{X}$ and $\mathrm{Y}$ chromosomes, and I know from Albert Camus' essay that Sisyphus is Happy. Each atom of that stone, each mineral flake of that night-filled mountain, in itself, forms a world. The struggle itself toward the heights is enough to fill a man's heart. One must imagine Sisyphus happy [1].

\section{References}

1. Albert Camus. The Myth of Sisyphus, 1942 Éditions Gallimard, in French, 1955 Hamish Hamilton, in English.

2. Payne Melissa, "Discussion of the Absurd in Albert Camus' Novels Essays and Journals" (1992). University of Tennessee Honors Thesis Projects. $\quad$ https://trace.tennessee.edu/utk chanhonoproj/93

(c) 2019 Sandor G. Vari. This is an open-access article distributed under the terms of the Creative Commons Attribution License, which permits unrestricted use, distribution, and reproduction in any medium, provided the original author and source are credited. 